Paweł ANTKOWIAK

DOI : $10.14746 / \mathrm{pp} .2020 .25 .2 .8$

Adam Mickiewicz University in Poznań

ORCID ID: 0000-0002-5371-1805

Joanna RADZIOCH

Adam Mickiewicz University in Poznań

\title{
Działalność Straży Miejskiej Miasta Poznania w latach 2015-2019
}

\begin{abstract}
Streszczenie: Istotnym elementem modelu samorządowego w Polsce jest niewątpliwie funkcjonująca od początku jego restytucji w Polsce straż gminna. Obchodzona w tym roku okrągła rocznica przywrócenia w Polsce samorządu terytorialnego jest okazją do wielu podsumowań i wyciągania wniosków na przyszłość. O ile w przypadku dyskusji na temat funkcjonowania samorządu terytorialnego w Polsce próżno poszukiwać głosów, które mówiłyby o próbie wycofania się z reformy samorządowej, o tyle w dyskusji publicznej coraz częściej pojawia się postulat likwidacji straży gminnych z polskiego systemu bezpieczeństwa publicznego. Warto jednak, dyskutując na temat zasadności funkcjonowania straży gminnych, oprzeć się na materiale źródłowym, który w jasny i klarowny sposób obrazuje zakres jej działań i tym samym opisuje pełnioną rolę w systemie bezpieczeństwa publicznego na poziomie lokalnym. Celem niniejszego opracowania jest przede wszystkim scharakteryzowanie działań jednostki we wskazanych latach, które świadczą o zasadności jej istnienia w mieście wojewódzkim, jakim jest Poznan.
\end{abstract}

Słowa kluczowe: straż miejska, samorząd terytorialny, Poznań, bezpieczeństwo, porządek publiczny

\section{Wprowadzenie}

stotnym elementem modelu samorządowego w Polsce jest niewątpliwie funkcjonująca od początku jego restytucji straż gminna, w miastach nazywana strażą miejską. Często w odniesieniu do tego rodzaju jednostek używa się również nazwy ,policja municypalna". Obchodzona w tym roku okrągła rocznica przywrócenia w Polsce samorządu terytorialnego jest okazją do wielu podsumowań i wyciągania wniosków na przyszłość. O ile w przypadku dyskusji na temat funkcjonowania samorządu terytorialnego w Polsce próżno poszukiwać głosów, które mówiłyby o próbie wycofania się z reformy samorządowej, o tyle w dyskusji publicznej coraz częściej pojawia się postulat likwidacji straży gminnych z polskiego systemu bezpieczeństwa publicznego. Głosy te szczególnie przybierają na sile w okresie samorządowych kampanii wyborczych, co najwyraźniej dało się odnotować w roku 2014, kiedy to temat likwidacji tego rodzaju jednostek stał się jednym z motorów napędowych ówczesnej kampanii wyborczej (Antkowiak, 2016, s. 73).

Warto jednak, dyskutując na temat zasadności funkcjonowania straży gminnych, oprzeć się na materiale źródłowym, który w jasny i klarowny sposób obrazuje zakres jej działań i tym samym opisuje pełnioną rolę w systemie bezpieczeństwa publicznego na poziomie lokalnym. Celem niniejszego opracowania jest przede wszystkim scharakteryzowanie działań jednostki we wskazanych latach, które świadczą o zasadności 
jej istnienia w mieście wojewódzkim, jakim jest Poznań. W swojej pracy autorzy określą, jaka jest rola straży miejskiej w zapewnieniu bezpieczeństwa i porządku publicznego w Poznaniu oraz jakie argumenty podnoszone są w dyskusji na temat likwidacji tej formacji $\mathrm{w}$ gminach - a w tym w mieście Poznaniu. Ponadto, scharakteryzowane zostanie, jakie działania podejmowane są przez Straż Miejską Miasta Poznania w zapewnieniu bezpieczeństwa i porządku publicznego na terenie tej gminy. Autorzy w sposób szczególny zwrócą uwagę na fakt, czy w badanych latach liczba zgłoszeń przyjmowanych przez formację wzrosła lub spadła. Celem artykułu jest również określenie, czy instytucja straży miejskiej powinna funkcjonować w Poznaniu. Badanie zostało przeprowadzone metodą analizy treści o charakterze jakościowym, co wynika $\mathrm{z}$ faktu, że nie zastosowano tutaj liczbowego schematu kodowego (Johnson, Reynolds, Mycoff, 2010, s. 301-302).

\section{Początki straży miejskiej w Poznaniu}

Straż gminna (miejska) powstała już w roku 1991. Początkowo funkcjonowała ona bezpośrednio w oparciu o przepisy ustawy z dnia 8 marca 1990 r. o samorządzie terytorialnym (Dz. U. 1990, Nr 16, poz. 95, z późn. zm.). Pierwotnie jednym z kluczowych obowiązków gmin stało się zaspakajanie zbiorowych potrzeb mieszkańców, wśród których można wyróżnić utrzymanie porządku publicznego oraz zapewnienie bezpieczeństwa obywateli (Marcinek, 2014, s. 21-38). Kluczowy przepis będący podstawą do tworzenia straży gminnych został wpisany w ustawę z dnia 6 kwietnia $1990 \mathrm{r}$. o Policji (Dz. U. 1990, Nr 30, poz. 179, z późn. zm.). Art. 23 ust. 1 omawianej ustawy brzmiał „burmistrzowie i prezydenci miast mogą w porozumieniu z Ministrem Spraw Wewnętrznych tworzyć umundurowane straże miejskie”. Zakres działań, czynności oraz uprawnień straży miejskich określony miał być przez statut nadany przez burmistrza lub prezydenta miasta w porozumieniu z Ministrem Spraw Wewnętrznych.

Idea utworzenia straży miejskich w formie osobnego aktu prawnego została zapoczątkowana przez samorządowców zrzeszonych w Związku Miast Polskich. Jej funkcją miało być zapewnienie porządku na terenach miejskich oraz odciążenie w zakresie zapewnienia bezpieczeństwa Policji. Podział miał być jasny - Policja odpowiadać będzie w głównej mierze za bezpieczeństwo, straż miejsca zaś za porządek publiczny. Uchwalenie ustawy z dnia 29 sierpnia 1997 r. o strażach gminnych (Dz. U. 2016, poz. 706, z późn. zm.) w 1997 roku spowodowało, że stały się one nową formacją, traktowaną od tej pory jako instytucja samorządowa, a nie policyjna (Mączyński, 1999, s. 45). Warto wskazać, że Trybunał Konstytucyjny w jednym z wyroków podkreślił znaczenie straży gminnej, określając wprost pracę strażników jako służbę (Wyrok).

Jak zaznacza W. Matuszewski pierwowzorem poznańskiej straży miejskiej - podobnie zresztą jak miało to miejsce w wielu innych miastach w Polsce - była Miejska Służba Porządkowa, która została utworzona w 1988 r. na podstawie ustawy z dnia 16 września 1982 r. o pracownikach urzędów państwowych (Dz. U. 1982, Nr 31, poz. 214, z późn. zm). Pierwsza utworzona Miejska Służba Porządkowa składała się z kilkunastu pracowników, którzy w zakresie swoich obowiązków posiadali uprawnienia w zakresie porządku na ulicach miasta. W efekcie przemian ustrojowych należało przebudować istniejące 
struktury - początkowo w oparciu o przepisy dotyczące funkcjonowania Policji oraz samorządu terytorialnego. Co ciekawe, w Poznaniu nowo powołana formacja w początkowej fazie swojego funkcjonowania nosiła nazwę Straż Miejska - Policja Municypalna (Zarządzenie nr 4/91). Jednakże od samego początku nazwa ta budziła wątpliwości natury prawnej, co w efekcie doprowadziło do zmiany nazwy na Straż Miejska, która funkcjonuje do dziś. Od połowy 1991 r. struktura straży opierała się na trzech jednostkach: Komendzie straży zlokalizowanej w Urzędzie Miasta przy pl. Kolegiackim oraz 2 oddziałach terenowych na Piątkowie oraz na Winogradach. Realizowane były również kursy kwalifikacyjne na stanowisko strażnika, które prowadził Ośrodek Szkolenia Policji w Poznaniu. W początkowej fazie funkcjonowania straży posiadała ona pełne poparcie władz samorządowych. Trzeba jednak pamiętać, że brakowało precyzyjnych uprawnień tej formacji, co powodowało wzrost liczby interwencji oraz rozszerzanie zadań strażników przede wszystkim w obszarze wykroczeń, kontrolowania stanu sanitarnego placówek handlowych i targowisk, kontroli przepisów prawa handlowego i praw konsumenckich. Z biegiem kolejnych lat następował sukcesywny rozwój i rozrost Straży Miejskiej w Poznaniu. Powstawały kolejne sekcje dzielnicowe w delegaturach dzielnicowych Urzędu Miasta. Bardzo istotnym wydarzeniem było rozpoczęcie funkcjonowania całodobowej służby dyżurnej z numerem alarmowym 986. Powstał również przy placu Kolegiackim oddział interwencyjny (Matuszewski, 2016, s. 19-21). W 2005 r. doszło do zmian i przeobrażono strukturę w Straż Miejską Miasta Poznania, którą wyłączono ze struktury organizacyjnej Urzędu Miasta Poznania. Od tej pory jednostka stanowiła samodzielną jednostkę budżetową (Uchwała nr LXXXIX/886/IV/2005). Od tego czasu w jednostce dochodziło do zmian strukturalnych, a także w zakresie uprawnień strażników i zadań samych straży.

W późniejszych latach funkcjonowania straży gminnych/miejskich w Polsce pojawiało się jednak coraz więcej wątpliwości na temat zakresu ich kompetencji oraz zasadności finansowania tego rodzaju służby ze środków własnych samorządu gminnego. Warto więc przyjrzeć się aktualnym rozwiązaniom dotyczącym zakresu kompetencji strażników miejskich, jak również argumentom poruszanym w sporze na temat funkcjonowania tego rodzaju jednostek.

\section{Rola straży miejskiej w zapewnieniu bezpieczeństwa i porządku publicznego}

Zgodnie z przepisami prawa, rada gminy ma możliwość utworzenia straży gminnej po zasięgnięciu opinii właściwego terytorialnie komendanta wojewódzkiego (stołecznego) Policji, o czym zawiadamia wojewodę. W gminach, w których organem wykonawczym jest burmistrz (prezydent miasta), straż tę określa się „strażą miejską”. Odpowiednio, rada gminy może rozwiązać straż po zasięgnięciu opinii właściwego terytorialnie komendanta wojewódzkiego (stołecznego) Policji, o czym również zawiadamia wojewodę. Co istotne - straż utrzymywana jest budżetu danej gminy. Strażą kieruje komendant, zatrudniany na podstawie umowy o pracę przez wójta, burmistrza, prezydenta miasta (Czaban, 2016, s. 55-72). Do podstawowych zadań straży należy w szczególności: ochrona spokoju i porządku w miejscach publicznych, czuwanie nad porządkiem i kontrola ruchu 
drogowego, kontrola publicznego transportu zbiorowego, współdziałanie z właściwymi podmiotami $\mathrm{w}$ zakresie ratowania życia i zdrowia obywateli, pomocy w usuwaniu awarii technicznych i skutków klęsk żywiołowych oraz innych miejscowych zagrożeń, zabezpieczenie miejsca przestępstwa, katastrofy lub innego podobnego zdarzenia albo miejsc zagrożonych takim zdarzeniem przed dostępem osób postronnych lub zniszczeniem śladów i dowodów, do momentu przybycia właściwych służb, a także ustalenie, w miarę możliwości, świadków zdarzenia, ochrona obiektów komunalnych i urządzeń użyteczności publicznej, informowanie społeczności lokalnej o stanie i rodzajach zagrożeń, a także inicjowanie i uczestnictwo $\mathrm{w}$ działaniach mających na celu zapobieganie popełnianiu przestępstw i wykroczeń oraz zjawiskom kryminogennym i współdziałanie w tym zakresie z organami państwowymi, samorządowymi i organizacjami społecznymi czy konwojowanie dokumentów, przedmiotów wartościowych lub wartości pieniężnych dla potrzeb gminy (Ustawa, art. 11).

Ponadto, wskazać należy, że podczas wykonywania swoich obowiązków strażnik ma prawo do takich czynności jak: udzielanie pouczeń, zwracanie uwagi, ostrzeganie bądź stosowanie innych środków oddziaływania wychowawczego, sprawdzanie osób w uzasadnionych przypadkach w celu ustalenia ich tożsamości, ujęcie jednostek, które w oczywisty sposób stwarzają bezpośrednie zagrożenie dla życia, zdrowia ludzkiego i mienia oraz doprowadzenia ich do najbliższej jednostki Policji, przeprowadzania kontroli osobistej, przeglądania zawartości podręcznych bagaży osoby, np. w sytuacji uzasadnionego podejrzenia popełnienia czynu zabronionego pod groźbą kary przeprowadzania czynności wyjaśniających, kierowania wniosków o ukaranie do sądu, oskarżania przed sądem i wnoszenia środków odwoławczych (Górnik, 2009).

Oczywistym jest, że działalność straży gminnych w aspekcie ochrony bezpieczeństwa i porządku publicznego ma charakter subsydiarny w stosunku do organów administracji rządowej, wśród których dominującą pozycję zajmuje Policja (Dajerling, 2016, s. 8592). Należy jednak zwrócić uwagę, że straż gminna/miejska wpisuje się znakomicie w system bezpieczeństwa publicznego na poziomie lokalnym, zwiększając tym samym poczucie bezpieczeństwa i wpływając na zapobieganie naruszeniom prawa. Oczywistą zaletą straży jest ciągła obecność na ulicach gminy/miasta oraz bezpośrednia podległość organom gminy. Elementy te powinny wpływać na zapewnienie mieszkańcom poczucia bezpieczeństwa oraz wpływać dyscyplinująco na ich zachowania (Lis, 2014, s. 16). Praktyka stosowania wskazanych powyżej kompetencji, a przede wszystkim opinia społeczna na ten temat często prowadzi do rozważań nad zasadnością istnienia tego rodzaju formacji na poziomie gminy. Temat ten staje się niejednokrotnie, szczególnie w okresie samorządowej kampanii wyborczej, przedmiotem dyskusji.

\section{Spór wokól funkcjonowania straży gminnych w Polsce}

Bezsporne jest to, że w pewnym momencie funkcjonowania w społecznym odbiorze straże gminne kojarzyły się opinii publicznej przede wszystkim jako narzędzie reperowania budżetów gminnych wpływami z fotoradarów instalowanych przez te służby czy mandatów za parkowanie w miejscu niedozwolonym. Oba typy działań, które często dominowały w działaniach poszczególnych jednostek straży, miały charakter uciążliwy 
dla mieszkańców - na co wskazują analizy prowadzone w całej Polsce. W związku z tym pojawiały się pytania, czy z budżetu gminnego powinno się dotować organizację, która zamiast działać na rzecz mieszkańców wytacza często działa przeciwko nim. Straże odgrywają jednak bardzo pożyteczną rolę przy przeciwdziałaniu drobnym naruszeniom bezpieczeństwa i porządku publicznego, np. niszczeniu wspólnego mienia, zaśmiecaniu miast czy porządku i bezpieczeństwa na ulicach. Wiele samorządów finansuje także wspólne patrole Policji i straży gminnej/miejskiej w newralgicznych punktach miast. Przynosi to bardzo dobre efekty - po pierwsze, nawiązywane są osobiste relacje między przedstawicielami obu służb, co w sytuacjach nadzwyczajnych i niestandardowych, gdzie wymagana będzie ścisła współpraca obu jednostek, może się okazać kluczowe. Po drugie zaś, wydaje się, że praca strażników w kooperacji z Policją podnosi kwalifikacje zawodowe tych pierwszych, ale wpływa również pozytywnie na wachlarz umiejętności zawodowych policjantów.

Warto również odnotować, że skuteczność realizacji zadań nakładanych sukcesywnie na te formacje zależy w dużej mierze od zakresu przyznanych im uprawnień. Ważne jest jednak to, aby zakres posiadanych uprawnień, jakie daje im ustawa był wprost proporcjonalny do nałożonych na nich zadań. Zagrożeniem, na które czasem zwracają uwagę strażnicy jest fakt, że na strażników przerzucane są kolejne obowiązki bez odpowiedniego ich wyposażenia w środki finansowe oraz zabezpieczenia stosownego zakresu kompetencji. Trzeba też pamiętać, że działalność straży gminnych jest nieustannie weryfikowana zarówno przez administrację rządową (Informacja o działalności straży gminnych/miejskich w 2014; Wnioski), jak i zewnętrzne instytucje kontrolne, w tym przede wszystkim Najwyższą Izbę Kontroli (Podstawy; Informacja o wynikach kontroli funkcjonowania; Informacja o wynikach kontroli działalności). NIK zajmowała się między innymi analizą podstaw prawnych działania straży gminnych, praktyką ich funkcjonowania oraz drażliwym społecznie tematem, jakim była kontrola działalności jednostek samorządu terytorialnego w zakresie przeprowadzania kontroli prędkości pojazdów uczestniczących w duchu drogowym. O ile większość uwag czy zarzutów ma charakter w dużej mierze porządkujący, o tyle niepokojący jest fakt, że uwagi zgłaszane przez organy rządowe czy instytucje kontrolne mają charakter powtarzający się. Inaczej natomiast wygląda sytuacja, gdy badania dotyczące jakości pracy i świadczonych usług publicznych w zakresie porządku i bezpieczeństwa publicznego prowadzą same jednostki straży (Wyniki ankiety dotyczacej Straży; Wyniki ankiety dotyczacej oceny). Wówczas rysowany obraz jest dużo bardziej korzystny i w większości z nich próbuje się udowadniać tezę, że funkcjonowanie tego rodzaju jednostek jest niezbędnym elementem lokalnej administracji.

Mimo poczynionych uwag funkcjonowanie straży gminnych trwale wpisało się już w lokalną sferę administracji bezpieczeństwa i porządku publicznego. Równolegle zjawiskiem, które przybiera na sile jest likwidowanie istniejących już straży na kanwie społecznego niezadowolenia $\mathrm{z}$ dotychczasowego ich działania oraz politycznego interesu. Często podkreśla się w tego rodzaju dyskusji fakt, że są one nadmiernym obciążeniem w budżecie gminy, nie przynosząc jednocześnie oczekiwanych efektów w sferze lokalnej. Argumenty ekonomiczne zaczynają przeważać nad merytorycznymi. W tym kontekście pojawiają się również postulaty, aby te same pieniądze przeznaczyć na doposażenie Policji czy uruchomienie nowych etatów, aniżeli opłacanie osobnej służby, która - zda- 
niem wielu zwolenników tej tezy - wykonuje często podobne zadania i posiada niższe kompetencje aniżeli funkcjonariusze Policji.

Problemem, który ma swoje odniesienie również do sfery wizerunkowej straży gminnej, jest to, że tak jak wszystkie inne pola działalności władz lokalnych, tak i funkcjonowanie i działalność straży gminnej winna mieć charakter usługowy i służebny wobec mieszkańców. Tymczasem praktyka działania, której najbardziej wymiernym przykładem była tzw. ,polityka radarowa”, służąca zapełnianiu dziury budżetowej poprzez masowe nakładanie mandatów przy użyciu fotoradarów nie zawsze zgodnie z obowiązującym prawem dotyczącym ich wykorzystania, pokazują że obszar działania straży oraz motywacja do działania bywały zgoła odmienne od założonych. Dla przykładu strażnicy gminni w 2012 r. nałożyli 1803722 grzywien w drodze mandatu karnego, na łączną sumę 241682 180,50 zł, z czego najwięcej za wykroczenia przeciwko bezpieczeństwu w komunikacji - 1462 072, co stanowi około 81\% wszystkich sankcji w postępowaniu mandatowym (Informacja o działalności straży gminnych/miejskich w 2012). Mimo że wolą ustawodawcy strażnicy nie używają już tego rodzaju urządzeń, to wypracowany na przestrzeni lat wizerunek strażników z fotoradarem w ręku trwale wpisał się już w świadomość obywateli i nadal promieniuje na współczesny sposób ich postrzegania. O uciążliwości działań wobec mieszkańców możemy również mówić w przypadku stosowania przez nich blokad kół samochodów niewłaściwie zaparkowanych czy nakładania mandatów pieszym za przechodzenie w niedozwolonym miejscu przez jezdnię. Wszystko to sprawia, że pozostała - całkiem spora - sfera ich aktywności jest niemalże społecznie niezauważalna. W opinii publicznej utarł się również pogląd mówiący o tym, że strażnicy nie podejmują się w ogóle interwencji w sytuacjach trudnych, wymagających specjalistycznej wiedzy oraz umiejętności.

Jak zauważa również K. Jankowiak, działania strażników opierają się na współpracy ze społecznością lokalną i różnymi instytucjami, które zgłaszają bardzo szerokie spektrum wykroczeń. To sprawia, że ich praca związana jest z rozwiązywaniem wielu ludzkich problemów, z którymi mają trudności obywatele, urzędnicy, instytucje, etc. Strażnik według społecznego odczucia musi więc być specjalistą od wszystkich spraw nękających nasze społeczeństwo. Obywatelom zależy przecież na porządku publicznym i bezpieczeństwie, kiedy następuje wzrost wszelkiej patologii i brutalizacji życia w ich lokalnej społeczności (Jankowiak, 2014, s. 217-227).

\section{Działalność Straży Miejskiej Miasta Poznania w latach 2015-2019}

Warto więc sprawdzić, jak wygląda aktywność Straży Miejskiej Miasta Poznania w badanym przedziale czasu. Okazuje się bowiem, że wraz z rozwojem społeczno-gospodarczym oraz pojawianiem się nowych form zagrożeń - straże elastycznie dostosowują zakres swojego działania do aktualnych potrzeb.

Od 2012 roku w Mieście Poznaniu funkcjonuje aplikacja o nazwie „Interwencje - Poznań", w której po zainstalowaniu, użytkownicy mogą zgłaszać potrzebę interwencji służb miejskich. Każde zgłoszenie można uzupełnić o fotografię wykonaną przy użyciu urządzenia mobilnego. Rozwiązanie to ma ułatwić komunikację między mieszkańcami a władzami miasta. Jest to dostosowanie się do potrzeb obywateli w zakresie rozwoju 
nowych technologii. Ponadto, mieszkańcy mają też możliwość zgłaszania potrzeby interwencji przez całodobowy numer 986, a także przez e-mail: sm@um.poznan.pl. Miasto Poznań skonstruowało również specjalny formularz dostępny na stronie internetowej www.sm.poznan.pl, który ma ułatwić zgłoszenie sprawy. Liczbę przyjętych zgłoszeń w latach 2015-2019 zaprezentowano na wykresie 1.

\section{Wykres 1. Liczba zgloszeń przyjętych przez dyżurnego Straży Miejskiej Miasta Poznania}

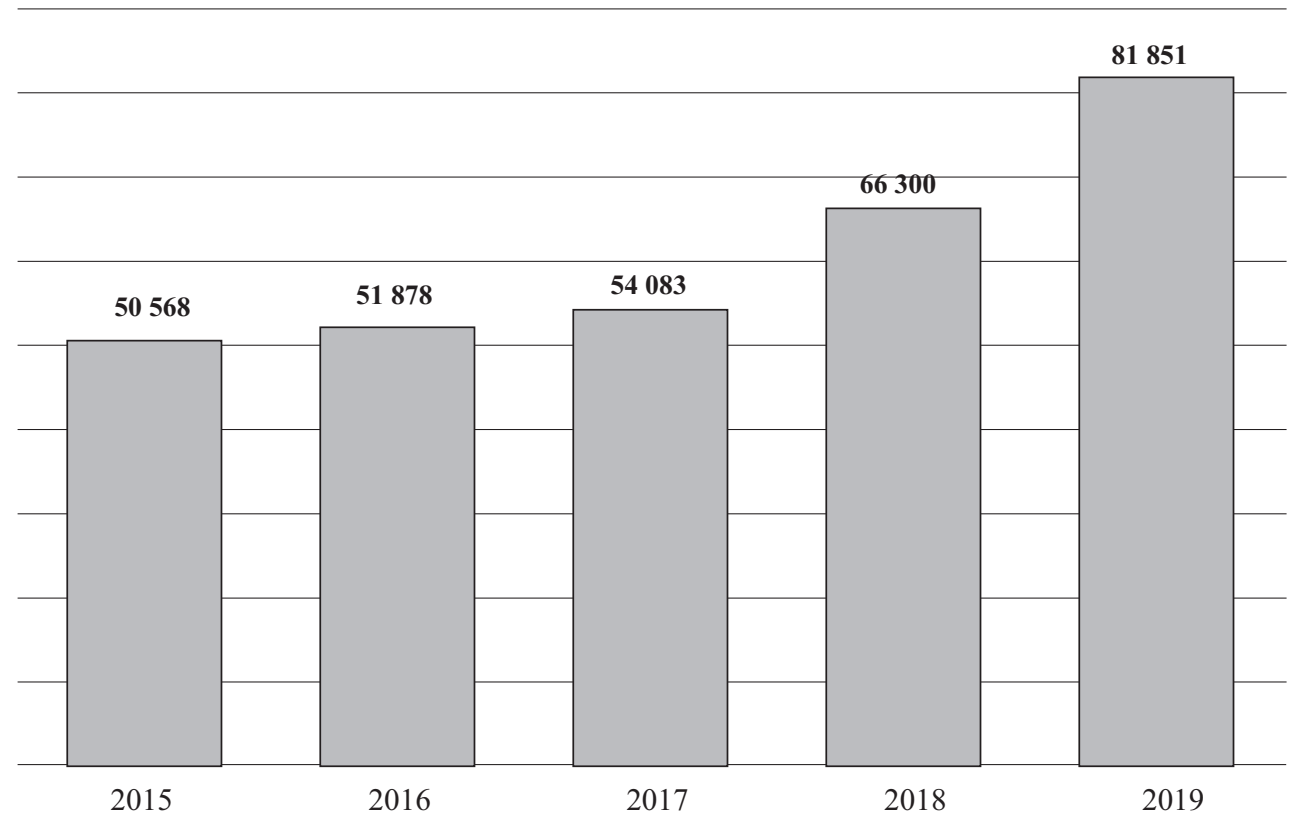

Źródło: Opracowanie własne na podstawie raportów z działalności Straży Miejskiej Miasta Poznania z lat 2015-2019.

Na zaprezentowanym powyżej wykresie zaobserwować można wzrost liczby zgłoszeń przyjętych przez Straż Miejską Miasta Poznania. Szczególnie w dwóch ostatnich badanych latach odnotowano wyraźny wzrost liczby przyjmowanych zgłoszeń. Co interesujące, pomimo spadku liczby mieszkańców z 544612 w 2015 r. do 537642 w 2018 r. (Główny), notuje się coraz więcej zgłoszeń. Sytuacja ta może być wynikiem rosnącej świadomości mieszkańców w zakresie funkcjonowania i zadań straży miejskiej, a także ich dostępności dla mieszkańców miasta. Wzrost liczby przyjętych zgłoszeń może być również wynikiem dysponowania zwiększonymi siłami i środkami z Centrum Zarządzania Kryzysowego Miasta Poznania, gdzie to dyżurny podejmuje decyzję o tym, jaka służba będzie niezbędna do interwencji na miejscu zdarzenia.

Liczba osób, wobec których zastosowano środki prawne w latach 2015-2018 wzrosła dynamicznie z poziomu niecałych 40000 do ponad 60000 , co obrazuje wykres 2 . Zaobserwować można również, że w ostatnim analizowanym roku liczba jednak nieznacznie spadła. Jest to ciekawe zjawisko w stosunku do wykresu pierwszego. Wzrost liczby zgłoszeń nie jest związany z liczbą osób, wobec których zastosowano środki 
prawne. Wniosek z powyżej zależności może oznaczać, że zmienia się charakter przyjmowanych zgłoszeń. Nie każde działanie podejmowane przez strażników musi być zakończone mandatem lub innym możliwym środkiem prawnym. Należy mieć na uwadze, że Poznań jest miastem, w którym organizowane jest wiele imprez masowych oraz sportowych. Straż miejska jest obecna podczas zabezpieczania terenu organizacji takiego wydarzenia.

Wykres 2. Liczba osób wobec których zastosowano środki prawne

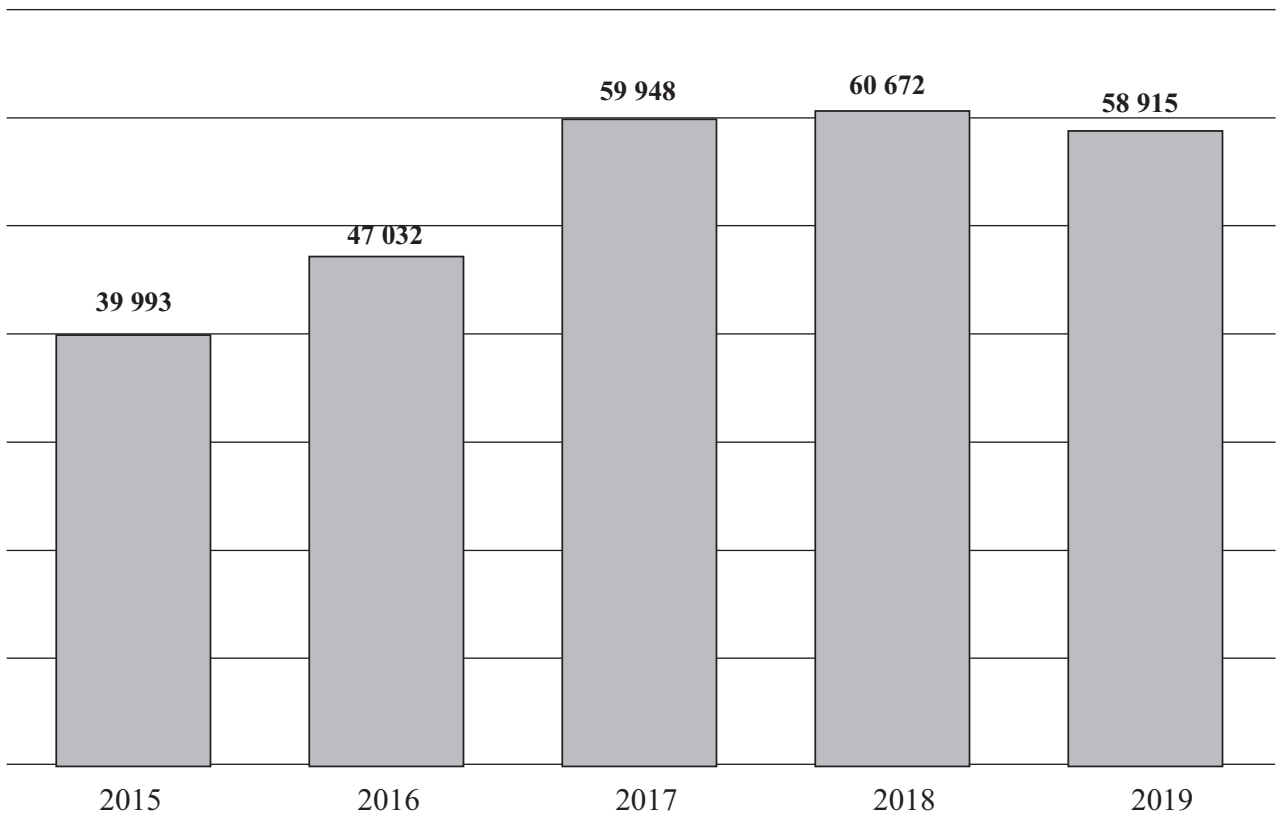

Źródło: Opracowanie własne na podstawie raportów z działalności Straży Miejskiej Miasta Poznania z lat 2015-2019.

Dane przedstawione na wykresie 3 obrazują, ile samochodów zostało odholowanych ze względu na pozostawienie ich w miejscach niedozwolonych lub w taki sposób, że zagrażały one bezpieczeństwu, bądź tamowały ruch. Zaobserwować można, że wartości przedstawione na wykresie zmieniają się dynamicznie. Nie można scharakteryzować jednostajnego wzrostu ani spadku w zakresie działalności w tym obszarze. W 2019 roku odnotowano najwięcej takich działan. Realizacja zadań, które w sposób szczególny służą mieszkańcom, jest wpisana w Strategię Rozwoju Miasta Poznania do roku 2030. Zgodnie z zapisami zawartymi w dokumencie, celem gminy jest sprawienie, aby miasto stało się miastem wygodnym i przyjaznym do zamieszkania, w którym zapewnione zostały warunki przestrzenne $\mathrm{i}$ techniczne do realizacji potrzeb mieszkańców. W związku ze spadkiem liczby osób mieszkających w Poznaniu, ale przy jednoczesnym wzroście liczby samochodów w mieście (Strategia, s. 85), stworzenie komfortowych warunków do parkowania ma szczególne znaczenie. Wydaje się, że zwiększona aktywność straży w tym zakresie jest wynikiem stosownym dyspozycji wydanych przez włodarzy miasta. 
Wykres 3. Liczba odholowanych aut pozostawionych w miejscach zabronionych, które zagrażały bezpieczeństwu lub tamowały ruch w latach 2015-2019

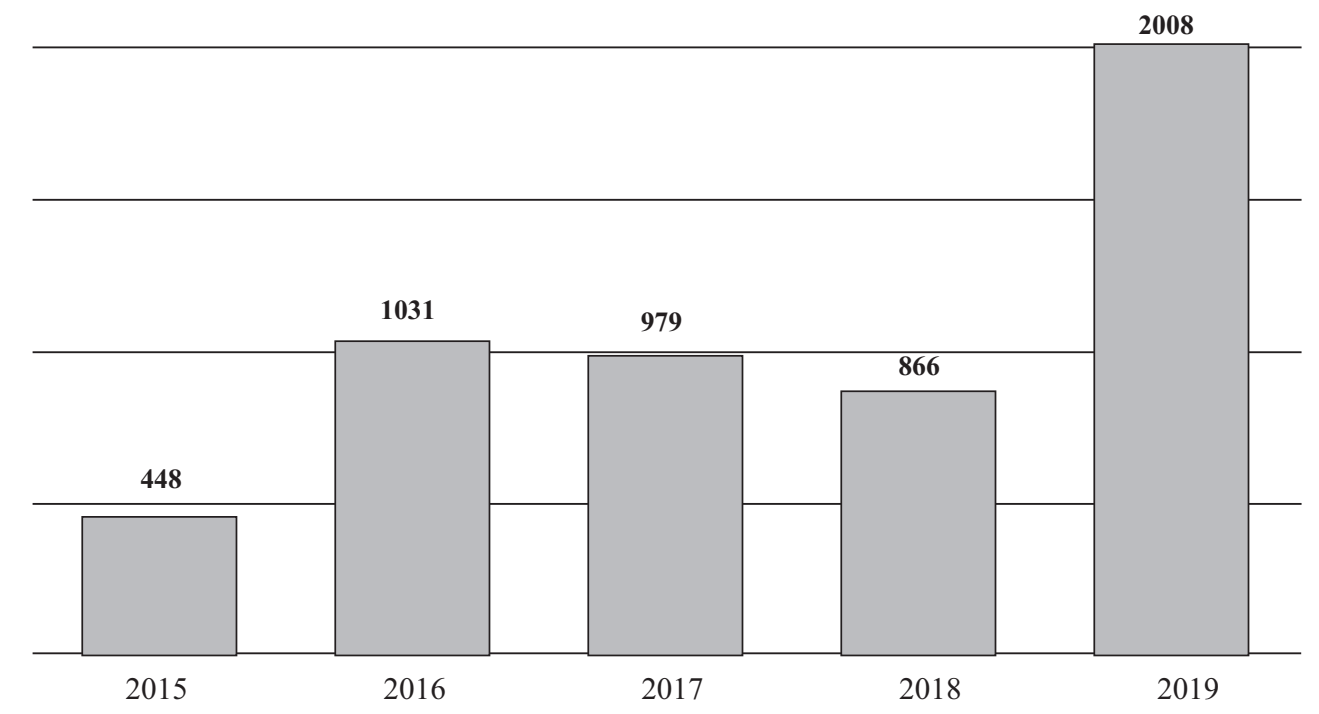

Źródło: Opracowanie własne na podstawie raportów z działalności Straży Miejskiej Miasta Poznania z lat 2015-2019.

Nowe wyzwania stawiane przed jednostkami samorządu terytorialnego dotyczące między innymi ochrony środowiska - przede wszystkich ochrony naszego powietrza - determinują również podejmowanie nowych aktywności w tym obszarze przez straże gminne/miejskie. Nie inaczej jest w Mieście Poznaniu. Wykres 4 obrazuje dane dotyczące ilości podjętych interwencji związanych z kontrolą spalania w domowych instalacjach grzewczych lub ogniskach. W raporcie z 2015 roku nie znajdują się informacje dotyczące przeprowadzenia takich kontroli. Widać więc wyraźnie, że jest to nowy obszar aktywności straży miejskiej, powstały w odpowiedzi na społeczne zapotrzebowanie. Tematyka zanieczyszczenia powietrza wymusza na władzach lokalnych podjęcie działań z tego obszaru. Wzrost interwencji Straży Miejskiej Miasta Poznania w zakresie kontroli zapewnienia odpowiednich warunków spalania wydaje się więc być naturalną tego konsekwencją. Na przestrzeni zaledwie kilku lat zaobserwować można wzrost, ponad czterokrotny, podjętych interwencji. Tak z 676 kontroli w 2016 roku ilość ta wzrosła do 3276 w 2018 roku.

W badanych latach można również zaobserwować zmianę ilości osób, wobec których podjęto interwencje związane z piciem alkoholu w miejscach niedozwolonych, co szczegółowo obrazuje wykres 5. Wartości rosły w latach 2015-2017, następnie malały. Interesującym wydaje się być spory spadek liczby osób objętych tego typu interwencją w roku 2019. Wobec ogromnego wzrostu ilości zgłoszeń przyjętych przez dyżurnego, zarówno w latach 2018, jak i 2019, spadek wartości w tym zakresie budzi niepokój. 
Wykres 4. Interwencje w zakresie kontroli spalania w domowych instalacjach grzewczych lub ogniskach

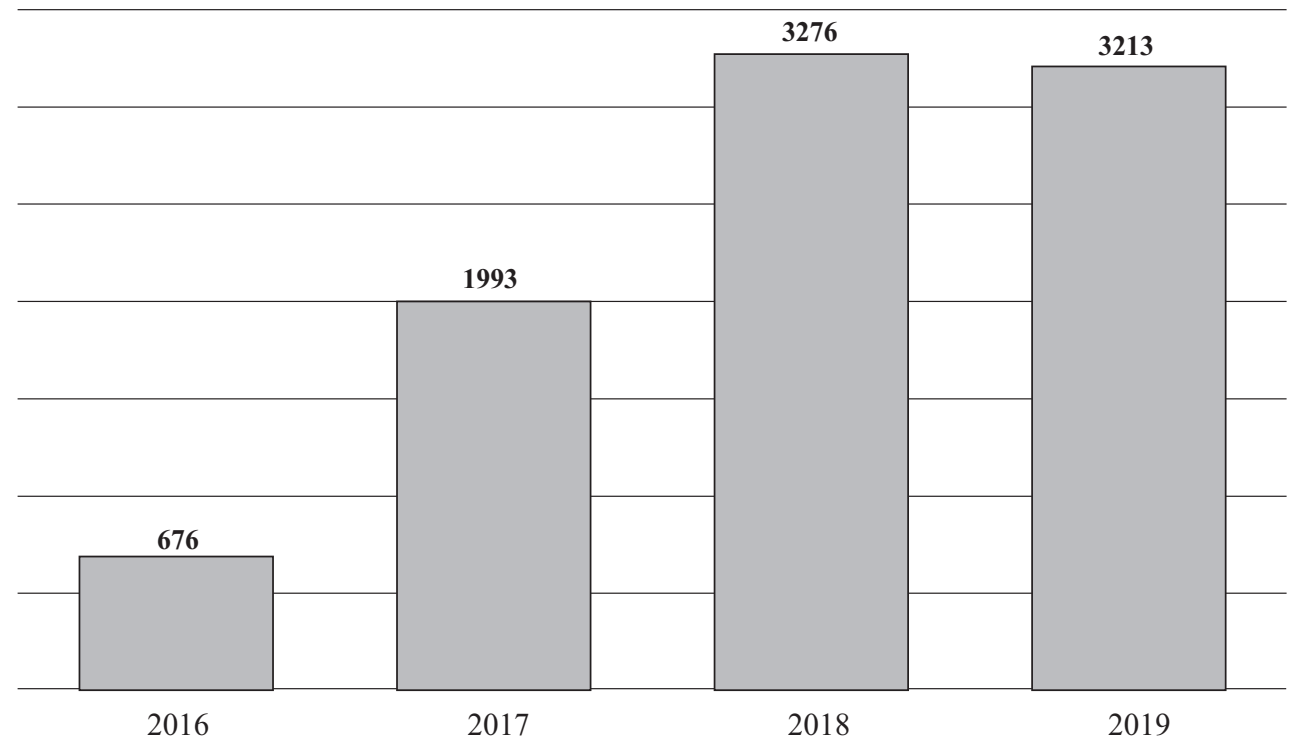

Źródło: Opracowanie własne na podstawie raportów z działalności Straży Miejskiej Miasta Poznania z lat 2015-2019.

Wykres 5. Liczba osób wobec których podjęto interwencję w związku ze spożywaniem alkoholu w miejscach zabronionych

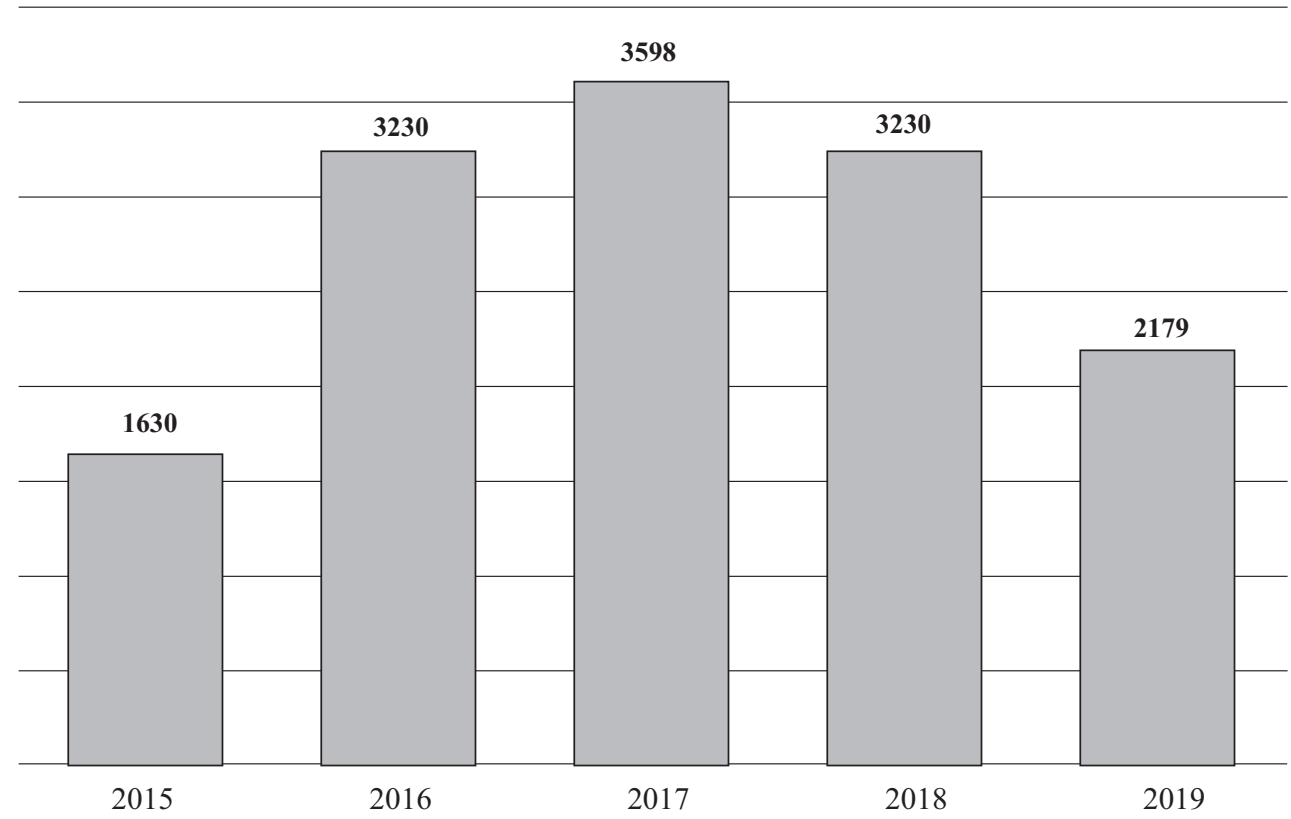

Źródło: Opracowanie własne na podstawie raportów z działalności Straży Miejskiej Miasta Poznania z lat 2015-2019. 


\section{Podsumowanie}

Działalność Straży Miejskiej Miasta Poznania w latach 2015-2019 w zakresie bezpieczeństwa i porządku publicznego była wielowymiarowa. Odnotować można zarówno czynności podejmowane $\mathrm{w}$ zakresie bezpieczeństwa $\mathrm{w}$ komunikacji, ale również te dotyczące osób spożywających alkohol w miejscach niedozwolonych. Należy mieć na uwadze również działania w zakresie kontroli czystości powietrza, które podejmowane są w związku ze spadającą jakością powietrza na całym świecie. Co istotne, zaobserwować można wzrost ilości zgłoszeń dokonanych do dyżurnego. Jest to szczególnie ważne, ze względu na rolę straży miejskiej w systemie zapewnienia bezpieczeństwa i porządku publicznego. Szczególne uprawnienia, jakie przysługują tej jednostce, sprawiają, że straż miejska może w sposób znaczący uzupełniać Policję w realizowaniu zadań. Subsydiarność rozwiązania wpływa na jakość życia mieszkańców oraz osób przyjezdnych. Fakultatywność implikacji straży miejskich pozostawia organom gminy dowolność w tym zakresie. Dzięki odpowiedniej analizie potrzeb mieszkańców oraz charakteru gminy określić można, czy wprowadzenie rozwiązania jest zasadne. Jest to o tyle istotne, że każdy samorząd terytorialny ma inną specyfikę oraz obszary, które wymagają szczególnej uwagi. Straż miejska w Poznaniu realizuje zadania wskazane w ustawie. Wzrost ilości zgłoszeń jest potwierdzeniem tego, że jednostka ta jest potrzebna.

Ostatnią kwestią, która nie była przedmiotem tego opracowania, ale warta jest wspomnienia, jest budowanie pozytywnego wizerunku formacji. Nie ulega bowiem wątpliwości, że jednym z kluczowych elementów wzmocnienia pozycji społecznej straży gminnej w danej wspólnocie lokalnej jest dbałość o pozytywny jej wizerunek i poprawne relacje z mieszkańcami. Wydaje się jednak, że w tej sferze jest jeszcze wiele do zrobienia, bowiem analiza działań z zakresu szeroko rozumianego public relations jednostek straży przynosi krytyczne konstatacje. Tymczasem dzisiaj, dzięki nowym technologiom, portalom społecznościowym etc., pojawiają się nowe przestrzenie i możliwości do autopromocji oraz nowe kanały informacyjne, które sprawnie wykorzystane przez straż w dłuższej perspektywie czasu pozytywnie wpłyną na ich wizerunek.

\section{Bibliografia}

Antkowiak P. (2016), Straż gminna w polskim systemie samorządowym - od idei do realizacji, w: Straż gminna. Oceny - wnioski - rekomendacje (1991-2016), red. J. Konieczny, M. Tomaszyk, Wydawnictwo Naukowe Wydziału Nauk Politycznych i Dziennikarstwa UAM, Poznań.

Czaban A. (2016), Straż miejska w systemie bezpieczeństwa. Analiza porównawcza rozwiązań krajowych z funkcjonujacymi w wybranych państwach, w: Straż gminna. Oceny - wnioski - rekomendacje (1991-2016), red. J. Konieczny, M. Tomaszyk, Wydawnictwo Naukowe Wydziału Nauk Politycznych i Dziennikarstwa UAM, Poznań.

Dajerling L. (2016), Straż gminna w systemie ochrony bezpieczeństwa i porzadku publicznego. Uwagi i wnioski, w: Straż gminna. Oceny - wnioski - rekomendacje (1991-2016), red. J. Konieczny, M. Tomaszyk, Wydawnictwo Naukowe Wydziału Nauk Politycznych i Dziennikarstwa UAM, Poznań.

Główny Urząd Statystyczny, https:/poznan.stat.gov.pl/files/gfx/poznan/pl/defaultstronaopisowa/ 1154/3/1/poznan_2019_dzial05.pdf, 8.03.2020. 
Górnik P. (2009), Podstawy prawne funkcjonowania oraz zadania straży gminnych, Wydawnictwo Szkoły Policyjnej w Katowicach, Katowice.

Informacja o działalności straży gminnych (miejskich) w 2012 r. (2012), Departament Porządku Publicznego MSW, Warszawa.

Informacja o działalności straży gminnych (miejskich) w 2014 r. oraz wspótpracy straży z Policja (2015), Departament Porządku Publicznego MSW, Warszawa.

Informacja o wynikach kontroli działalności jednostek samorządu terytorialnego $w$ zakresie przeprowadzania kontroli prędkości pojazdów uczestniczacych w ruchu drogowym (2011), Najwyższa Izba Kontroli, KKT-4114-02/2010, nr ewid. 151/2011/I/10/006/KKT, Warszawa.

Informacja o wynikach kontroli funkcjonowania straży gminnych (miejskich) (2011), Najwyższa Izba Kontroli, LSZ-4101-02-02/2010, nr ewid. 169/2010/P/10/167/LSZ, Szczecin.

Jankowiak K. (2014), Straż gminna/miejska formacja mundurowa czy pracownik administracji?, „Kultura Bezpieczeństwa. Nauka - Praktyka - Refleksje", nr 16.

Johnson J. B., Reynolds H. T., Mycoff J. D. (2010), Metody badawcze w naukach politycznych, Warszawa.

Lis W. (2014), Straże gminne systemie organów ochrony bezpieczeństwa i porządku publicznego, „Roczniki Nauk Prawnych”, tom XXIV, nr 1.

Marcinek P. (2014), Kompetencje Straży Miejskiej a bezpieczeństwo w mieście na przykładzie miasta Dębica, ,Security, Economy \& Law”, nr 5.

Matuszewski W. (2016), Rys historyczny straży miejskiej w Poznaniu, w: Straż gminna. Oceny - wnioski - rekomendacje (1991-2016), red. J. Konieczny, M. Tomaszyk, Wydawnictwo Naukowe Wydziału Nauk Politycznych i Dziennikarstwa UAM, Poznań.

Mączyński M. (1999), Ochrona bezpieczeństwa i porządku publicznego w Polsce przedrozbiorowej, w: Zapobieganie przestępczości w społecznościach lokalnych, red. J. Czapska, W. Krupiarz, Instytut Spraw Publicznych, Warszawa.

Podstawy prawne funkcjonowania oraz zadania straży gminnych (2016), Najwyższa Izba Kontroli, KAP.430.003.2015, nr ewid. 5/2016/P/15/006/KAP, Warszawa.

Strategia Rozwoju Miasta Poznania do roku 2030, Miasto Poznań.

Uchwała nr LXXXIX/886/IV/2005 Rady Miasta Poznania z dnia 11 października 2005 r. $w$ sprawie utworzenia jednostki budżetowej pod nazwa Straż Miejska Miasta Poznania.

Ustawa z dnia 29 sierpnia 1997 r. o strażach gminnych, Dz. U. 2016, poz. 706, z późn. zm.

Wnioski z dnia 21 grudnia 2015 roku do działania straży gminnych (miejskich) funkcjonujacych na terenie województwa świętokrzyskiego na 2016 rok (2016), Kielce.

Wyniki ankiety dotyczacej oceny pracy Straży Gminnej w Kobylnicy przeprowadzonej wśród społeczności lokalnej (2012), Kobylnica.

Wyniki ankiety dotyczącej Straży Miejskiej przeprowadzonej wśród mieszkańców Jarosławia (2013), Jarosławiec.

Wyrok Trybunatu Konstytucyjnego z dnia 23 września 1997 r., sygn. K 25/96, OTK 1997/3-4/36.

Zarządzenie nr 4/91 Prezydenta Miasta Poznania z dnia 1 marca 1991 r. w sprawie utworzenia Straży Miejskiej Poznania.

\section{Activities of the City Guard in Poznań in 2015-2019}

\section{Summary}

An important element of the local government model in Poland is undoubtedly the city guard functioning since the beginning of its restitution in Poland. The anniversary of the restoration of local 
government in Poland this year is an opportunity for many summaries and to draw conclusions for the future. While in the case of discussions on the functioning of local government in Poland, there is no search for voices that would say about an attempt to withdraw from local government reform, the postulate of liquidating municipal guards from the Polish public security system is increasingly appearing in public discussion. However, when discussing the legitimacy of the functioning of city guards, it is worth relying on source material, which clearly and clearly depicts the scope of its activities and thus illustrates its role in the public security system at the local level. The purpose of this study is primarily to characterize the activities of the individual in the years indicated, which prove the legitimacy of its existence in the provincial city, which is Poznań.

Key words: Municipal Police, local government, Poznan, security and public order 
